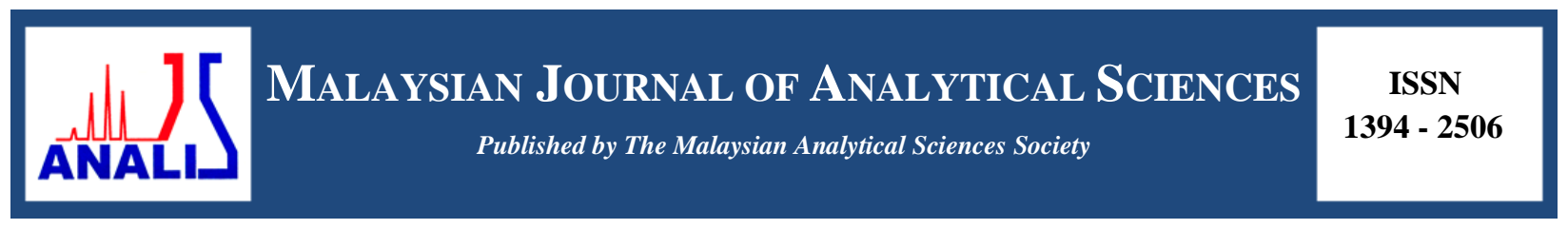

\title{
A-NOR STEROIDS FROM THE MARINE SPONGE, Clathria SPECIES
}

\author{
(Steroid A-nor daripada Span Laut, Spesies Clathria) \\ Idin Sahidin ${ }^{1}$, Carla Wulandari Sabandar ${ }^{1}$, Wahyuni ${ }^{1}$, Rini Hamsidi ${ }^{1}$, Muhammad Hajrul Malaka $^{1}$, Baru Sadarun ${ }^{2}$, \\ La Ode Aslan ${ }^{2}$ \\ ${ }^{1}$ Faculty of Pharmacy \\ ${ }^{2}$ Faculty of Fisheries and Marine Science \\ Universitas Halu Oleo, Kendari 93232, Indonesia \\ *Corresponding author: sahidin02@yahoo.com
}

Received: 22 August 2017; Accepted: 20 March 2018

\begin{abstract}
Chemical compounds classified as A-nor steroids (1-4) were isolated from a marine sponge of the Clathria sp., collected from Southeast Sulawesi, Indonesia. Of these, one new compound, clathruhoate (1) was elucidated as $3 \beta$ (butyryloxymethyl)- $A$-nor-5 $\alpha$-cholestane. All compounds were obtained using silica gel chromatography techniques and their structures were determined based on 1D and 2D NMR spectroscopic measurements and comparison with values from literature. Meanwhile, all compounds were inactive for antimicrobial activity.
\end{abstract}

Keywords: Clathria sp., marine sponge, $A$-nor steroid, $3 \beta$-(Butyryloxymethyl)- $A$-nor-5 $\alpha$-cholestane

\begin{abstract}
Abstrak
Sebatian kimia diklasifikasikan sebagai steroid A-nor (1-4) telah diasingkan daripada span laut Clathria yang dikumpul dari Sulawesi Tenggara, Indonesia. Satu sebatian baharu, klathruhoat (1) telah ditentukan sebagai $3 \beta$ (butiriloksimetil)- $A$-nor-5 $\alpha$-kolestan. Semua sebatian diperoleh dengan menggunakan teknik kromatografi gel silika dan struktur sebatian-sebatian ini telah ditentukan menggunakan spektroskopi 1D dan 2D NMR dan dengan perbandingan nilai dari kajian literatur. Sementara itu, semua sebatian didapati tidak aktif terhadap aktiviti antimikrob.
\end{abstract}

Kata kunci: Clahtria sp., span laut, steroid $A$-nor, $3 \beta$-(Butiriloksimetil)- $A$-nor-5 $\alpha$-kolestan

\section{Introduction}

The diversity of marine species in the Indonesian Archipelago has been recognized worldwide [1,2], and various species of sponges have been discovered in east Indonesia [3, 4]. The genus Clathria from the family Microcionidae is classified as Demospongia and contains approximately 544 accepted species worldwide [5]. Of these, some species from the marine regions of Australia, Argentina, Indo-Pacific, Korea, Panama, Philippines and New Zealand have been phytochemically investigated and found to contain alkaloids [6-12], amides [13], peptides [14, 15], anthraquinones [16], and terpenoids [17-23]. Meanwhile, biological activities including antibacterial [7, 11, 21, 22], anti-HIV [18], cytotoxicity towards cancer cell lines [9, 10, 13, 14, 22], anti-inflammatory [19], and antiplasmodial [24] have been attributed to the species in the genus Clathria. 
In our extensive study on the diversity and chemistry of Indonesian marine sponges, we investigated the chemical constituents of Clathria sp. from the Southeast Sulawesi marine region. The investigation resulted in the isolation and elucidation of one new $A$-nor steroid (1), together with three known $A$-nor steroids (2-4). The isolated compounds (1-4) were also evaluated for their antimicrobial activity.

\section{Chemicals}

\section{Materials and Methods}

Solvents used were distilled technical grades. Aluminium sheets kieselgel $60 \mathrm{PF}_{254} 0.25 \mathrm{~mm}$ (Merck 1.05554), silica gel $60 \mathrm{HF}_{254} 5-40 \mu \mathrm{m}$ (Merck 1.07747), and silica gel $60 \mathrm{GF}_{254}$ 5-40 $\mu \mathrm{m}$ containing gypsum (Merck 1.07749) were used to perform thin layer chromatography (TLC), vacuum liquid chromatography (VLC), and radial chromatography (RC), respectively. Nutrient agar (NA), nutrient broth (NB), potato dextrose agar (PDA), potato dextrose broth (PDB), chloramphenicol, ketoconazole, and DMSO were used for antimicrobial assays.

\section{Animal material}

Samples of Clathria sp. (Figure 1) were collected by hand using SCUBA (Self Contained Underwater Breathing Apparatus) from the reef slope area $\left(70^{\circ}\right)$ of the Bintang Samudra Marine Education Park, Southeast Sulawesi, Indonesia, at a depth of 2-10 m, in May 2015. Samples $(6.5 \mathrm{~kg})$ were stored in ice and brought back shortly afterwards to the laboratory for further analysis. A sponge specimen was identified by the staffs of the Faculty of Fisheries and Marine Science of Universitas Halu Oleo with the registration number UHO-2015-03.

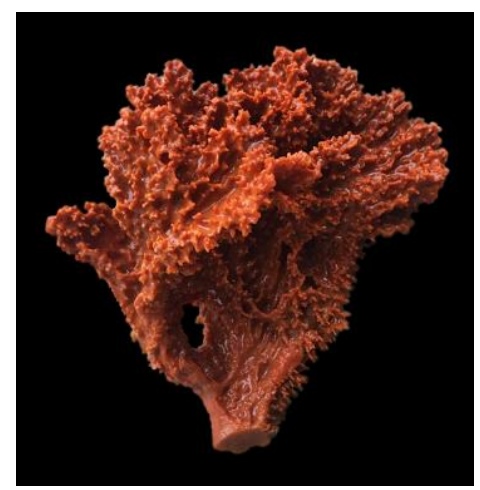

Figure 1. A photograph of the investigated Clathria sp.

\section{Extraction and isolation}

The dried powdered sponge (4 kg) was macerated with $\mathrm{MeOH}(3 \times 8 \mathrm{~L}, 24 \mathrm{~h}$ each time $)$ at room temperature and filtered. The solvent was evaporated under reduced pressure to yield the $\mathrm{MeOH}$ extract in the form of a brownishyellow gum $(300 \mathrm{~g})$. A portion of this extract $(30 \mathrm{~g})$ was fractionated using silica gel vacuum liquid chromatography (VLC) $(13 \times 5 \mathrm{~cm})$ with a gradient elution of $n$-hexane/EtOAc $(9: 1,8: 2,7: 3,5: 5$, v/v) to produce five main fractions (F1-F5). Fraction F1 (2 g) was subjected to a silica gel radial chromatography (RC) and eluted isocratically with $n$ hexane/EtOAc $(9.5: 0.5, \mathrm{v} / \mathrm{v})$ to yield nine subfractions $\left(\mathrm{F} 1_{1}-\mathrm{F} 1_{9}\right)$. The combined subfractions $\mathrm{F} 1_{1}-\mathrm{F} 1_{3}(1.36 \mathrm{~g})$ were further separated on a silica gel RC with an elution of $n$-hexane/ $\mathrm{CHCl}_{3}(9.5: 0.5, \mathrm{v} / \mathrm{v})$ to afford compound $\mathbf{1}(30 \mathrm{mg})$. Purification of subfraction $\mathrm{F}_{4}(0.14 \mathrm{~g})$ using a silica gel RC with $n$-hexane/ $\mathrm{CH}_{2} \mathrm{Cl}_{2}(6: 4$, v/v) as its mobile phase yielded compound $2(23 \mathrm{mg})$. Fraction F2 $(10 \mathrm{~g})$ was subjected to a silica gel VLC $(10 \times 5 \mathrm{~cm})$, eluted with $n$ hexane/EtOAc (9:1-0:10, v/v), and given eight subfractions $\left(\mathrm{F} 2{ }_{1}-\mathrm{F} 2{ }_{8}\right)$. Subfraction $\mathrm{F} 2{ }_{4}(0.8 \mathrm{~g})$ was purified using silica gel RC with $n$-hexane/EtOAc/acetone $(7: 1: 0.5, \mathrm{v} / \mathrm{v})$ as its mobile phase to give compound 3 (200 $\mathrm{mg}$ ). Purification of subfraction $\mathrm{F}_{6}(1.1 \mathrm{~g})$ on a silica gel RC with the elution of $n$-hexane/EtOAc/acetone $(7: 1: 0.5, \mathrm{v} / \mathrm{v})$ yielded compound 4 (120 mg). 


\section{Characterization study}

The infrared (IR) analysis of compounds was performed using a Nicolet iS5 spectrophotometer with iD5 ATR (Thermo Scientific, Waltham, MA, USA). The HRESI-MS spectra were measured using a Waters QTOF mass spectrometer (Milford, MA, USA). Meanwhile, the ${ }^{1} \mathrm{H},{ }^{13} \mathrm{C}$, and 2D NMR spectra were recorded using a JEOL ECP $500 \mathrm{MHz}$ (Tokyo, Japan) or an Agilent DD2 $500 \mathrm{MHz}$ (Agilent Technologies, Inc., Santa Clara, California, USA) spectrometers.

\section{In vitro antimicrobial assay}

Antimicrobial assay for the isolated compounds was performed using an agar well diffusion method towards E. coli ATCC 35218, S. aureus ATCC 25923, and C. albicans ATCC 10231 according to the previous method [30]. The development of microbial growth in a Petri dish was assisted using semisolid media. For bacterial growth, a semisolid medium containing sterilized nutrient agar (NA) $(20 \mathrm{~g} / \mathrm{L})$ and nutrient broth $(\mathrm{NB})(0.8 \mathrm{~g} / 0.1 \mathrm{~L})$ was prepared. Meanwhile, a semisolid medium for fungal growth was prepared with sterilized potato dextrose agar (PDA) $(65 \mathrm{~g} / \mathrm{L})$ and potato dextrose broth (PDB) $(2.4 \mathrm{~g} / 0.1 \mathrm{~L})$. One $\mathrm{mL}$ of microbial suspension (turbidity of 0.5 McFarland at $600 \mathrm{~nm})$ was added into NB $(5 \mathrm{~mL})$ or PDB $(5 \mathrm{~mL})$ and mixed. Solutions of tested compounds were prepared with concentrations of $0.1,0.2$, and $0.3 \%$ in DMSO $(10 \%$, v/v). Chloramphenicol and ketoconazole each in $0.1 \%(\mathrm{v} / \mathrm{v})$ were used as respective positive controls for bacteria and fungi, while DMSO was used as a negative control. The solid medium $(10 \mathrm{~mL})$ was poured into Petri dishes and allowed to solidify. Onto the solid medium, holes for samples were punched aseptically with tips. After that, the liquid medium-containing microbial suspension was evenly spread onto the surface of the solid medium. Samples $(100 \mu \mathrm{L})$ were then added to their respective holes and the Petri dishes were incubated at $37{ }^{\circ} \mathrm{C}$ for 24 hours (bacteria) and 72 hours (fungi). Antimicrobial activity was evaluated by measuring the diameter of the clear zone around the hole. The inhibition zone of compounds and positive controls is categorized as strong $(10-20 \mathrm{~mm})$, moderate $(5-10 \mathrm{~mm})$, and weak $(<5 \mathrm{~mm})$.

\section{Characterization of isolated compounds}

\section{Results and Discussion}

Purification of the methanol extract of the dried powdered Clathria sp. using silica gel vacuum liquid chromatography (VLC) and radial chromatography (RC) techniques yielded one new $A$-nor steroid, clathruhoate (1) and other known $A$-nor steroids (2-4). Structures of these compounds are displayed in Figure 2.
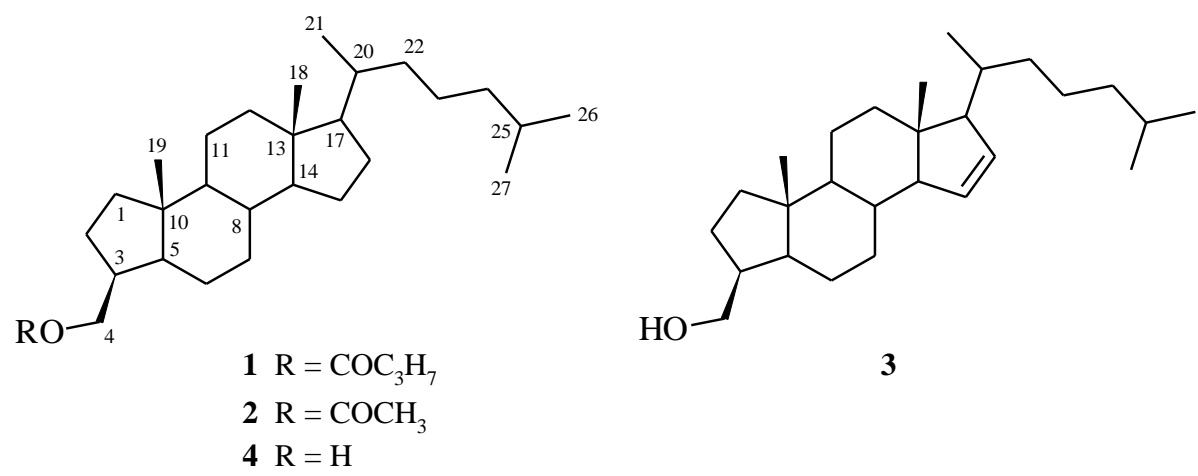

Figure 2. Chemical structures of compounds 1-4

By comparing the values between spectroscopic measurements and literatures data, compounds 2-4 were identified as $3 \beta$-(acetoxymethyl)- $A$-nor-5 $\alpha$-cholestane (2) [25], 3 $\beta$-(hydroxymethyl)- $A$-nor-5 $\alpha$-cholest-15-ene (3) [25, 26], and $3 \beta$-(hydroxymethyl)- $A$-nor-5 $\alpha$-cholestane (4) [25]. $A$-nor sterols are produced by marine Demosponges (e.g Axinella sp., Homoaxinella sp., Phakellia sp.) [25-28] via conversion of dietary sterols [29]. The occurrence of compounds 3 and $\mathbf{4}$ have been described in species Axinella [27, 28] and Homoaxinella [25], while the acetylation of compound 4 produced compound 2 [25]. Herein we report compound $\mathbf{2}$ as a natural product of the investigated Clathria sp. To our knowledge, the occurrence of these compounds in the genus Clathria is firstly reported in this work. 
Idin et al: $A$-NOR STEROIDS FROM THE MARINE SPONGE, Clathria SPECIES

$3 \beta$-(butyryloxymethyl)- $A$-nor-5 $\alpha$-cholestane (1)

White solid. HRMS-ESI: $\mathrm{m} / z$, $459.4112[\mathrm{M}+\mathrm{H}]^{+}$(calculated for $\left.\mathrm{C}_{31} \mathrm{H}_{55} \mathrm{O}_{2}{ }^{+}: 459.4197\right)$. ATR-FTIR $\left(v_{\max }, \mathrm{cm}^{-1}\right)$ : 2922, 2853, 1734, 1464, 1379, 1173, 968, 723. ${ }^{1} \mathrm{H}$ and ${ }^{13} \mathrm{C}$ NMR data are listed in Table 1.

Table 1. NMR data of compounds $\mathbf{1 - 4}\left(125 \mathrm{MHz}\right.$ for ${ }^{13} \mathrm{C}$ and $500 \mathrm{MHz}$ for ${ }^{1} \mathrm{H}$, in $\mathrm{CDCl}_{3}, \delta$, ppm, J/Hz)

\begin{tabular}{|c|c|c|c|c|c|}
\hline \multirow{2}{*}{$\mathrm{C}$ atom } & \multicolumn{2}{|r|}{1} & \multirow{2}{*}{$\frac{2}{\delta_{\mathrm{C}}}$} & \multirow{2}{*}{$\begin{array}{c}\mathbf{3} \\
\boldsymbol{\delta}_{\mathrm{C}}\end{array}$} & \multirow{2}{*}{$\begin{array}{c}4 \\
\delta_{\mathrm{C}} \\
\end{array}$} \\
\hline & $\delta_{\mathrm{C}}$ & $\delta_{\mathbf{H}}$ & & & \\
\hline 1 & 39.0 & $1.08(1 \mathrm{H}, \mathrm{m}), 1.61(1 \mathrm{H}, \mathrm{m})$ & 39.1 & 39.9 & 39.1 \\
\hline 2 & 27.3 & $1.44(1 \mathrm{H}, \mathrm{m}), 1.94(1 \mathrm{H}, \mathrm{m})$ & 22.8 & 22.9 & 24.6 \\
\hline 3 & 38.5 & $2.31(1 \mathrm{H}, \mathrm{m})$ & 38.6 & 39.7 & 42.9 \\
\hline 4 & 68.3 & $\begin{array}{l}3.94(1 \mathrm{H}, \mathrm{dd}, \mathrm{J}=10.27,6.85) \\
4.09(1 \mathrm{H}, \mathrm{dd}, \mathrm{J}=10.27,6.85)\end{array}$ & 68.5 & 67.2 & 66.7 \\
\hline 5 & 52.4 & $1.44(1 \mathrm{H}, \mathrm{m})$ & 52.6 & 52.7 & 52.6 \\
\hline 6 & 24.4 & $1.04(1 \mathrm{H}, \mathrm{m}), 1.55(1 \mathrm{H}, \mathrm{m})$ & 27.5 & 27.4 & 27.4 \\
\hline 7 & 32.7 & $0.83(1 \mathrm{H}, \mathrm{m}), 1.74 \mathrm{~m}(1 \mathrm{H}, \mathrm{m})$ & 32.8 & 32.9 & 32.8 \\
\hline 8 & 35.8 & $1.36(1 \mathrm{H}, \mathrm{m})$ & 35.7 & 35.7 & 35.6 \\
\hline 9 & 55.4 & $0.73 \mathrm{~m}(1 \mathrm{H}, \mathrm{m})$ & 55.6 & 55.6 & 55.5 \\
\hline 10 & 44.1 & - & 44.3 & 44.2 & 44.1 \\
\hline 11 & 22.8 & $1.31(2 \mathrm{H}, \mathrm{m})$ & 23.4 & 24.6 & 22.8 \\
\hline 12 & 39.5 & $1.14(2 \mathrm{H}, \mathrm{m})$ & 39.5 & 36.3 & 39.9 \\
\hline 13 & 43.1 & - & 43.1 & 43.1 & 43.1 \\
\hline 14 & 56.3 & $0.99(1 \mathrm{H}, \mathrm{m})$ & 56.4 & 56.5 & 56.5 \\
\hline 15 & 23.8 & $1.14(1 \mathrm{H}, \mathrm{m}), 1.34(1 \mathrm{H}, \mathrm{m})$ & 24.6 & 130.0 & 24.6 \\
\hline 16 & 29.3 & $1.26(2 \mathrm{H}, \mathrm{m})$ & 28.3 & 131.1 & 28.3 \\
\hline 17 & 56.2 & $1.00(1 \mathrm{H}, \mathrm{m})$ & 56.4 & 56.4 & 56.4 \\
\hline 18 & 12.2 & $0.66(3 \mathrm{H}, \mathrm{s})$ & 12.3 & 12.3 & 12.1 \\
\hline 19 & 14.5 & $0.78(3 \mathrm{H}, \mathrm{s})$ & 14.6 & 14.7 & 14.4 \\
\hline 20 & 35.5 & $1.29((1 \mathrm{H}, \mathrm{m})$ & 35.9 & 29.8 & 35.8 \\
\hline 21 & 18.7 & $0.91(3 \mathrm{H}, \mathrm{m})$ & 18.9 & 18.9 & 18.7 \\
\hline 22 & 36.2 & $0.99(2 \mathrm{H}, \mathrm{m})$ & 36.3 & 35.9 & 36.2 \\
\hline 23 & 23.2 & $1.33(1 \mathrm{H}, \mathrm{m}), 1.44(1 \mathrm{H}, \mathrm{m})$ & 23.0 & 24.6 & 23.9 \\
\hline 24 & 39.9 & $1.14(1 \mathrm{H}, \mathrm{m}), 1.95(1 \mathrm{H}, \mathrm{m})$ & 40.0 & 40.0 & 39.5 \\
\hline 25 & 28.2 & $1.24(1 \mathrm{H}, \mathrm{m}), 1.81(1 \mathrm{H}, \mathrm{m})$ & 28.2 & 28.2 & 28.0 \\
\hline 26 & 22.7 & $0.86(3 \mathrm{H}, \mathrm{m})$ & 22.7 & 22.7 & 22.7 \\
\hline 27 & 22.6 & $0.86(3 \mathrm{H}, \mathrm{m})$ & 22.6 & 23.0 & 22.7 \\
\hline $1^{\prime}$ & 174.1 & - & 171.5 & & \\
\hline $2^{\prime}$ & 34.5 & $2.27(2 \mathrm{H}, \mathrm{t}, \mathrm{J}=7.83)$ & 21.2 & & \\
\hline 3 ' & 22.5 & $1.63(2 \mathrm{H}, \mathrm{m})$ & & & \\
\hline $4{ }^{\prime}$ & 14.1 & $0.89(3 \mathrm{H}, \mathrm{m})$ & & & \\
\hline
\end{tabular}

Compound 1 was isolated as a white solid and was found to have a molecular formula of $\mathrm{C}_{31} \mathrm{H}_{55} \mathrm{O}_{2}$ (MW 458.41238) based on a HRESI-MS analysis at $\mathrm{m} / z 459.4112[\mathrm{M}+\mathrm{H}]^{+}$, requiring five degrees of unsaturation. Of 
these, one degree of unsaturation could be attributable to a carbonyl resonance ( $\delta$ 174.1), while the remaining degrees were denoted by four rings. The IR spectrum showed absorption bands of methyl and methylene groups at $2922 \mathrm{~cm}^{-1}$ ( $\mathrm{CH}_{3}$ stretching), $2853 \mathrm{~cm}^{-1}\left(\mathrm{CH}_{2}\right.$ stretching), $1464 \mathrm{~cm}^{-1}$ and $1379 \mathrm{~cm}^{-1}\left(\mathrm{CH}_{3}\right.$ and $\mathrm{CH}_{2}$ deformation) and an ester group at $1734 \mathrm{~cm}^{-1}\left(\mathrm{C}=\mathrm{O}\right.$ stretching) and $1173 \mathrm{~cm}^{-1}\left(\mathrm{C}-\mathrm{O}\right.$ stretching). The ${ }^{1} \mathrm{H}$ NMR spectrum showed signals representing five resonances of methyl protons at $\delta 0.66(\mathrm{H}-18), 0.78(\mathrm{H}-19), 0.86(\mathrm{H}-26, \mathrm{H}-27)$ and 0.91 $(\mathrm{H}-21)$ and two double doublet (dd) resonances of oxymethylene protons $(\mathrm{H}-4)$ at $\delta 3.94(\mathrm{~J}=10.27,6.85)$ and 4.09 $(\mathrm{J}=10.27,6.85)$, indicating a typical $3 \beta$-(hydroxymethyl)- $A$-nor cholestane $[25,26]$. In addition, a methyl group at $\delta$ 0.89 (H-4') and two methylenes at $\delta 1.63$ (H-3') and 2.27 (H-2') were observed in the spectrum, suggesting a butyryl group of an ester functionality in the structure as inferred in the IR analysis. In the ${ }^{13} \mathrm{C}$ NMR spectrum, thirty-one carbon signals were observed, thus supporting the results from the mass analysis. The carbon of oxymethylene of the $A$-nor steroid was resonanced at $\delta 68.3(\mathrm{C}-4)$ and one carbonyl of ester functionality was resonanced at $\delta 174.1\left(\mathrm{C}^{\prime} 1^{\prime}\right)$. The assignments of these protons and carbons in the skeleton of compound $\mathbf{1}$ were based on a HSQC analysis and are given in Table 1.

The presence of cholestane skeleton in compound 1 was verified using 2D NMR analyses, in particular, the HMBC measurement. Using this analysis, all carbons with the exception of C-2 $(\delta 27.3), \mathrm{C}-6(\delta 24.4), \mathrm{C}-11(\delta 22.8)$, and C-15 $(\delta 23.8)$ could be associated with one or more of the methyl groups based on ${ }^{2} J_{\mathrm{CH}}$ and ${ }^{3} J_{\mathrm{CH}}$ correlations (Figure 3). The patterns of these correlations were similar to the known compounds $\mathbf{2}$ and $\mathbf{4}$, which confirmed $\mathbf{1}$ as an $A$-nor cholestane. The oxymethylene protons at C-4 and methine proton at C-3 showed ${ }^{3} J_{\mathrm{CH}}$ and ${ }^{4} J_{\mathrm{CH}}$ correlations to a carbonyl carbon $(\delta 174.1)$ of an ester functionality, respectively, confirming the position of this carbonyl at $\mathrm{C}$ 1 '. The presence of a butyryloxy group $\left(\mathrm{C}_{3} \mathrm{H}_{7} \mathrm{COO}-\right)$ was confirmed using the observed correlations of the methyl (H-4') and methylenes (H-2', H-3') protons toward the carbonyl carbon C-1'. In addition, protons H-2' also showed ${ }^{4} J_{\mathrm{CH}}$ correlation to the oxymethylene carbon (C-4). Hence, this side group was attached to C-4. Based on these evidences, compound 1 was established as $3 \beta$-(butyryloxymethyl)- $A$-nor-5 $\alpha$-cholestane for which clathruhoate as a trivial name is proposed.

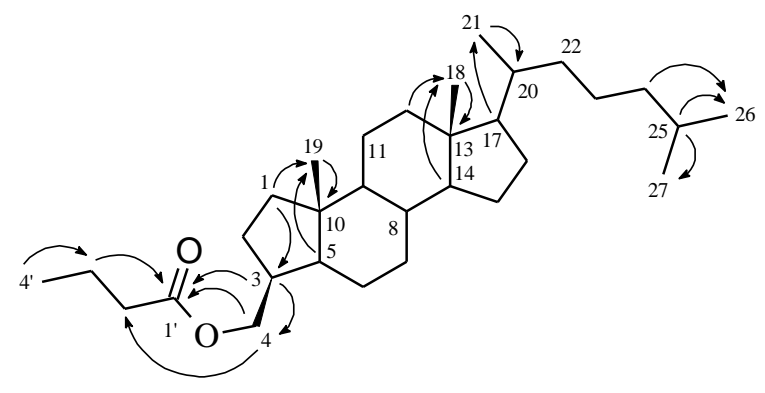

Figure 3. HMBC correlations $(\mathrm{H} \rightarrow \mathrm{C})$ of compound 1

\section{3 $\beta$-(acetoxymethyl)- $A$-nor-5 $\alpha$-cholestane (2)}

Yellow crystal. MW: $430.7061\left(\mathrm{C}_{29} \mathrm{H}_{50} \mathrm{O}_{2}\right)$. ATR-FTIR $\left(v_{\max }, \mathrm{cm}^{-1}\right): 2926,2858,1740,1455,1370,1164,969,721$; ${ }^{1} \mathrm{H}$ NMR $\left(\mathrm{CDCl}_{3}, 500 \mathrm{MHz}, \delta / \mathrm{ppm}, \mathrm{J} / \mathrm{Hz}\right): 4.09$ (1H, dd, J=10.27, 7.15, H-4a)), 3.95 (1H, t, J=8.4, H-4b), 2.33 (1H, m, H-3), 2.03 (3H, s, H-2'), 0.91 (3H, m, H-21), 0.86 (3H, m, H-27), 0.85 (3H, m, H-26), 0.75 (3H, s, H-19), 0.65 $(3 \mathrm{H}, \mathrm{s}, \mathrm{H}-18) .{ }^{13} \mathrm{C}$ NMR data are given in Table 1.

Compound 2 was obtained as a yellow crystal and gave a molecular formula of $\mathrm{C}_{29} \mathrm{H}_{50} \mathrm{O}_{2}$ (MW 430.7061) based on analyses using ${ }^{1} \mathrm{H}$ and ${ }^{13} \mathrm{C}$ NMR spectra. According to this formula, five degrees of unsaturation were calculated as denoted by a carbonyl resonance $(\delta 171.5)$ and four rings of the cholestane skeleton. The IR spectrum of compound 2 showed the presence of methyl and methylene groups $\left(2926,2858,1455,1370 \mathrm{~cm}^{-1}\right)$ and an ester group (1740, $1164 \mathrm{~cm}^{-1}$ ), which was similar to compound 1 . The ${ }^{1} \mathrm{H}$ NMR spectrum exhibited six resonances of methyl protons at $\delta 0.65$ (s, H-18), 0.75 (s, H-19), 0.85 (m, H-26), 0.86 (m, H-27), 0.91 (m, H-21) and 2.03 (s, H-2') and multiplet resonances of typical cholestane protons ranging from $\delta 0.83$ to 2.33 . The oxymethylene protons $(\mathrm{H}-4)$ were 
observed as a double doublet at $\delta 4.09(\mathrm{~J}=10.27,7.15, \mathrm{H}-4 \mathrm{a})$ and a triplet at $\delta 3.95(\mathrm{~J}=8.14, \mathrm{H}-4 \mathrm{~b})$. Meanwhile, the ${ }^{13} \mathrm{C}$ NMR spectra showed twenty-nine carbons in the skeleton of compound 2 (Table 1), and their values were identical to those given in [25]. Hence, compound 2 was deduced as $3 \beta$-(acetoxymethyl)- $A$-nor-5 $\alpha$-cholestane.

3 $\beta$-(hydroxymethyl)- $A$-nor-5 $\alpha$-cholest-15-ene (3)

White solid. MW: $386.6535\left(\mathrm{C}_{27} \mathrm{H}_{46} \mathrm{O}\right)$. ATR-FTIR $\left(v_{\max }, \mathrm{cm}^{-1}\right)$ : 3334, 2918, 2853, 1594, 1508, 1454, 1376, 1265 , 1035, 977. ${ }^{1} \mathrm{H}$ NMR $\left(\mathrm{CDCl}_{3}, 500 \mathrm{MHz}, \delta / \mathrm{ppm}, \mathrm{J} / \mathrm{Hz}\right): 5.15(1 \mathrm{H}, \mathrm{m}, \mathrm{H}-15), 5.13(1 \mathrm{H}, \mathrm{m}, \mathrm{H}-16), 3.71(1 \mathrm{H}, \mathrm{dd}$, $\mathrm{J}=10.45,6.50, \mathrm{H}-4 \mathrm{a}), 3.47(1 \mathrm{H}, \mathrm{t}, \mathrm{J}=9.72, \mathrm{H}-4 \mathrm{~b}), 2.22(1 \mathrm{H}, \mathrm{m}, \mathrm{H}-3), 1.95(2 \mathrm{H}, \mathrm{m}), 1.82(1 \mathrm{H}, \mathrm{m}), 0.90(3 \mathrm{H}, \mathrm{m}, \mathrm{H}-$ 21), $0.89(3 \mathrm{H}, \mathrm{m}, \mathrm{H}-27), 0.85(3 \mathrm{H}, \mathrm{m}, \mathrm{H}-26), 0.74(3 \mathrm{H}, \mathrm{s}, \mathrm{H}-19), 0.65(3 \mathrm{H}, \mathrm{s}, \mathrm{H}-18) .{ }^{13} \mathrm{C}$ NMR data are given in Table 1.

Compound 3 was obtained as a white solid. The compound has a molecular formula of $\mathrm{C}_{27} \mathrm{H}_{46} \mathrm{O}$ (MW 386.6535) based on ${ }^{1} \mathrm{H}$ and ${ }^{13} \mathrm{C}$ NMR spectral analyses and required five degrees of unsaturation, originating from one olefinic group $(\delta 130.0,131.1)$ and four rings of the cholestane structure. The IR spectrum displayed absorption bands of a hydroxyl group (3334 $\mathrm{cm}^{-1}$, OH stretching), methyl and methylenes groups $\left(2918,2853,1454,1376 \mathrm{~cm}^{-1}\right)$, and an alkene group (1594 $\mathrm{cm}^{-1}, \mathrm{C}=\mathrm{C}$ stretching). The ${ }^{1} \mathrm{H}$ NMR spectrum of compound 3 exhibited resonances of olefinic protons at $\delta 5.15(\mathrm{~m}, \mathrm{H}-15)$ and $5.13(\mathrm{~m}, \mathrm{H}-16)$, oxymethylene protons at $\delta 3.71(\mathrm{dd}, \mathrm{J}=10.45,6.50, \mathrm{H}-4 \mathrm{a})$ and 3.47 (t, J=9.72, H-4b), and methyl protons at $\delta 0.65(\mathrm{~s}, \mathrm{H}-18), 0.74(\mathrm{~s}, \mathrm{H}-19), 0.85(\mathrm{~m}, \mathrm{H}-26), 0.89(\mathrm{~m}, \mathrm{H}-27)$ and 0.90 $(\mathrm{m}, \mathrm{H}-21)$. The presence of a hydroxyl group in the IR spectrum and oxymethylene protons $(\delta 3.71,3.47)$ in the ${ }^{1} \mathrm{H}$ NMR spectrum suggested an alcohol functionality in compound 3. The ${ }^{13} \mathrm{C}$ NMR spectrum consisted of twentyseven carbons including two olefinic carbons $(\delta 130.0,131.1)$ and one oxymethylene carbon $(\delta 67.2)$ (Table 1). The NMR data of compound 3 were identical with those assigned for $3 \beta$-(hydroxymethyl)- $A$-nor- $5 \alpha$-cholest-15-ene [25, 26]. This compound was previously reported from Homoaxinella trachys [25], Phakellia aruensis [26], and Axinella proliferans [27].

\section{3 $\beta$-(hydroxymethyl)- $A$-nor-5 $\alpha$-cholestane (4)}

White solid. MW: $388.6694\left(\mathrm{C}_{27} \mathrm{H}_{48} \mathrm{O}_{2}\right)$. ATR-IR $\left(v_{\max }, \mathrm{cm}^{-1}\right)$ : 3357, 2915, 2820, 1454, 1378, 1276, 1196, 740; ${ }^{1} \mathrm{H}$ NMR $\left(\mathrm{CDCl}_{3}, 500 \mathrm{MHz}, \delta / \mathrm{ppm}, \mathrm{J} / \mathrm{Hz}\right): 3.70(1 \mathrm{H}, \mathrm{dd}, \mathrm{J}=10.3,6.3, \mathrm{H}-4 \mathrm{a}), 3.46(1 \mathrm{H}, \mathrm{t}, \mathrm{J}=9.6, \mathrm{H}-4 \mathrm{~b}), 2.23(1 \mathrm{H}, \mathrm{m}, \mathrm{H}-$ 3), $1.93(2 \mathrm{H}, \mathrm{m}), 1.82(1 \mathrm{H}, \mathrm{m}), 0.91(3 \mathrm{H}, \mathrm{m}, \mathrm{H}-21), 0.86(3 \mathrm{H}, \mathrm{m}, \mathrm{H}-27), 0.84(3 \mathrm{H}, \mathrm{m}, \mathrm{H}-26), 0.73$ (3H, s, H-19), $0.64(3 \mathrm{H}, \mathrm{s}, \mathrm{H}-18) .{ }^{13} \mathrm{C}$ NMR data are given in Table 1.

Compound 4 was isolated as a white solid and have a molecular formula of $\mathrm{C}_{27} \mathrm{H}_{48} \mathrm{O}_{2}$ (MW 388.6694). Four degrees of unsaturation calculated from this formula was attributed by four rings of the cholestane structure. The IR spectrum suggested a hydroxyl group $\left(3357 \mathrm{~cm}^{-1}\right)$ and methyl and methylenes groups $(2918,2853,1454,1376$ $\left.\mathrm{cm}^{-1}\right)$. The ${ }^{1} \mathrm{H}$ NMR spectrum showed two coupled peaks at $\delta 3.70(\mathrm{dd}, \mathrm{J}=10.3,6.3)$ and $3.46(\mathrm{t}, \mathrm{J}=9.6)$, indicating the mutual oxymethylene protons as previously observed in compounds 1-3. Similarly, five methyl groups of typical cholestane skeleton were observed at $\delta 0.64(\mathrm{~s}, \mathrm{H}-18), 0.73(\mathrm{~s}, \mathrm{H}-19), 0.84(\mathrm{~m}, \mathrm{H}-26), 0.86(\mathrm{~m}, \mathrm{H}-27)$ and 0.91 (m, H-21). Meanwhile, as many as twenty-seven carbons were obtained from the ${ }^{13} \mathrm{C}$ NMR spectrum and their values were identical to compounds 1-2 with the exception of butyryloxy and acetoxy carbons. Hence, compound 4 was determined as $3 \beta$-(hydroxymethyl)- $A$-nor- $5 \alpha$-cholestane [25]. This compound was previously reported from Axinella verrucosa [28].

\section{Antimicrobial activity of isolated compounds}

The isolated compounds were evaluated for antibacterial activity against E. coli, S. aureus, and antifungal activity against $C$. albicans. However, none of the tested compounds exhibited antibacterial and antifungal activities as compared to chloramphenicol and ketoconazole, respectively. To our knowledge, the antimicrobial activity of these compounds is reported for the first time in this study.

\section{Conclusion}

Four $A$-nor steroids were isolated and identified from the methanol extract of the marine sponge Clathria sp. in the genus Clathria for the first time, which are $3 \beta$-(butyryloxymethyl)- $A$-nor-5 $\alpha$-cholestane (1), $3 \beta$-(acetoxymethyl)- $A$ nor-5 $\alpha$-cholestane (2), $3 \beta$-(hydroxymethyl)- $A$-nor-5 $\alpha$-cholest-15-ene (3), and $3 \beta$-(hydroxymethyl)- $A$-nor-5 $\alpha$ cholestane (4). Compound 1 named as clathruhoate was established as a new compound from this species. The 
presence of these compounds could enrich the chemical diversity of the genus Clathria. Despite their inactive properties towards E. coli, S. aureus, and C. albicans, further studies are still required to explore more about the potent antimicrobial compounds from this species as well as other biological activities.

\section{Acknowledgment}

The authors thank the Ministry of Research, Technology, and Higher Education of the Republic of Indonesia for a research grant scheme (Hibah Kompetensi 2016) for financial support.

\section{References}

1. Spalding, M. D., Ravilious, C. and Green, E. P. (2001). World atlas of coral reefs. University of California Press, Berkeley, Los Angeles, CA: pp. $21-22$.

2. Mora, C., Chittaro, P. M., Sale, P. F., Kritzer, J.P. and Ludsin, S.A. (2003). Patterns and processes in reef fish diversity. Nature, 421: $933-936$.

3. van Soest, R. W. M. (1989). The Indonesia sponge fauna: a status report. Netherlands Journal of Sea Research, 23: $223-230$.

4. Soekarno, R. (1989). Comparative studies on the status of Indonesia coral reefs. Netherlands Journal of Sea Research, 23: $215-222$.

5. van Soest, R. (2017). Clathria Schmidt, 1982. In Wold Porifera Database. van Soest, R. W. M., Boury-Esnault, N., Hooper, J. N. A., Rützler, K., de Voogd, N. J., Alvarez de Glasby, B., Pisera, A. B., Manconi, R., Schoenberg, C., Klautau, M., Picton, B., Kelly, M., Vacelet, J., Dohrmann, M., Díaz, M. C., Cárdenas, P., Carballo, J. L. and Rios Lopez, P. (Eds). Accessed through: World Register of Marine Species (http://www.marinespecies.org/aphia.php?p=taxdetails\&id=131868 on 2017-07-23).

6. Sperry, S. and Crews, P. (1996). A novel alkaloid from the Indo-Pacific sponge Clathria basilana. Tetrahedron Letters, 37: $2389-2390$.

7. Capon, R. J., Miller, M. and Rooney, F. (2001). Mirabilin G: a new alkaloid from a southern Australian marine sponge, Clathria species. Journal of Natural Products, 64: 643 - 644.

8. Zuleta, I. A., Vitelli, M. L., Baggio, R., Garland, M. T., Seldes, A. M. and Palermo, J. A. (2002). Novel pteridine alkaloids from the sponge Clathria sp. Tetrahedron, 58: 4481 - 4486.

9. El-Naggar, M., Conte, M. and Capon, R. J. (2010). Mirabilins revisited: polyketide alkaloids from a southern Australian marine sponge, Clathria sp. Organic \& Biomolecular Chemistry, 8: 407 - 412.

10. Laville, R., Thomas, O. P., Berrué, F., Marquez, D., Vacelet, J. and Amade, P. (2009). Bioactive guanidine alkaloids from two Carribean marine sponges. Journal of Natural Products, 72: 1589 - 1594.

11. Sun, X., Sun, S., Ference, C., Zhu, W., Zhou, N., Zhang, Y. and Zhou, K. (2015). A potent antimicrobial compound isolated from Clathria cervicornis. Bioorganic \& Medicinal Chemistry Letters, 25: 67 - 69.

12. Wei, X., Henriksen, N. M., Skalicky, J. J., Harper, M. K., Cheatham, T. E., III, Ireland, C. M. and Van Wagoner, R. M. (2011). Araiosamines A-D: tris-bromoindole cyclic guanidine alkaloids from the marine sponge Clathria (Thalysias) araiosa. The Journal of Organic Chemistry, 76: 5515 - 5523.

13. Ohta, S., Okada, H., Kobayashi, H., Oclarit, J. M. and Ikegami, S. (1993). Clathrynamides A, B, and C: novel amides from a marine sponge Clathria sp. that inhibit cell division of fertilized starfish eggs. Tetrahedron Letters, 34: 5935 - 5938.

14. Davis, R. A., Mangalindan, G. C., Bojo, Z. P., Antemano, R. R., Rodriguez, N. O., Concepcion, G. P., Samson, S. C., de Guzman, D., Cruz, L. J., Tasdemir, D., Harper, M. K., Feng, X., Carter, G. T. and Ireland, C. M. (2004). Microcionamides A and B, bioactive peptides from the Philippine sponge Clathria (Thalysias) abietina. The Journal of Organic Chemistry, 69: 4170 - 4176.

15. Woo, J. -K., Jeon, J., Kim, C. -K., Sim, C. J., Oh, D. -C., Oh, K. -B. and Shin, J. (2013). Gombamide A, a cyclic thiopeptide from the sponge Clathria gombawuiensis. Journal of Natural Products, 76: 1380 - 1383.

16. Khokhar, S., Pierens, G. K., Hooper, J. N. A., Ekins, M. G., Feng, Y. and Davis, R. A. (2016). Rhodocomatulin-type anthraquinones from the Australian marine invertebrates Clathria hirsuta and Comatula rotalaria. Journal of Natural Products, 79: 946 - 953.

17. Capon, R. J., Miller, M. and Rooney, F. (2000). Clathrins A-C: metabolites from a southern Australian marine sponge, Clathria species. Journal of Natural Products, 63: 821 - 824.

18. Rudi, A., Yosief, T., Loya, S., Hizi, A., Schleyer, M. and Kashman, Y. (2001). Clathsterol, a novel anti-HIV-1 RT sulfated sterol from the sponge Clathria species. Journal of Natural Products, 64: 1451 - 1453. 
19. Keyzers, R. A., Northcote, P. T. and Webb, V. (2002). Clathriol, a novel polyoxygenated $14 \beta$ steroid isolated from the New Zealand marine sponge Clathria lissosclera. Journal of Natural Products, 65: 598 - 600.

20. Santalova, E. A., Makarieva, T. N., Gorshkova, I. A., Dmitrenok, A. S., Krasokhin, V. B. and Stonik, V. A. (2004). Sterols from six marine sponges. Biochemical Systematics and Ecology, 32: 153 - 167.

21. Gupta, P., Sharma, U., Schulz, T. C., McLean, A. B., Robins, A. J. and West, L. M. (2012). Bicyclic C21 terpenoids from the marine sponge Clathria compressa. Journal of Natural Products, 75: 1223 - 1227.

22. Woo, J. -K., Kim, C. -K., Kim, S. -H., Kim, H., Oh, D. -C., Oh, K. -B. and Shin, J. (2014). Gombaspiroketals A-C, sesterterpenes from the sponge Clathria gombawuiensis. Organic Letters, 16: 2826 - 2829.

23. Woo, J. -K., Kim, C. -K., Ahn, C. -H., Oh, D. -C., Oh, K. -B. and Shin, J. (2015). Additional sesterterpenes and a nortriterpene saponin from the sponge Clathria gombawuiensis. Journal of Natural Products, 78: 218 224.

24. Inbaneson, S. J. and Ravikumar, S. (2012). In vitro antiplasmodial activity of Clathria vulpina sponge associated bacteria against Plasmodium falciparum. Asian Pacific Journal of Tropical Disease, 2012: 319 323.

25. Eggersdorfer, M. L., Kokke, W. C. M. C., Crandell, C. W., Hochlowski, J. E. and Djerassi, C. (1982). Sterols in marine invertebrates. 32. ${ }^{1}$ Isolation of $3 \beta$-(hydroxymethyl)-A-nor-5 $\alpha$-cholest-15-ene, the first naturally occurring sterol with a 15-16 double bond. The Journal of Organic Chemistry, 47: 5304 - 5309.

26. Malik, S. and Djerassi, C. (1989). Minor and trace sterols in marine invertebrates. 61. Isolation and structure elucidation of new A-nor sterols from the marine sponge Phakellia aruensis. Steroids, 53: 271 - 284.

27. Aknin, M., Gaydou, E. M., Boury-Esnault, N., Constantino, V., Fattorusso, E. and Mangoni, A. (1996). Norsterols in Axinella proliferans, sponge from the Indian Ocean. Comparative Biochemistry and Physiology, 113: $845-848$.

28. Minale, L. and Sodano, G. (1974). Marine sterols: unique $3 \beta$-hydroxymethyl-A-nor- $5 \alpha$-steranes from the sponge Axinella verrucosa. Journal of the Chemical Society, Perkin Transactions I: 2380 - 2384.

29. Bibolini, L., Minale, L. and Sodano, G. (1978). Investigations on the ring contraction step in the biosynthesis of A-nor-stanols by the marine sponge Axinella verrucosa. Journal of the Chemical Society, Chemistry Communications: $524-525$.

30. Ngajow, M., Abidjulua, J. and Kamu, VS. (2013). Pengaruh antibakteri ekstrak kulit batang Matoa (Pometia pinnata) terhadap bakteri Staphylococcus aureus secara in vitro. Jurnal Mipa Unsrat Online, 2(2): 128 - 132. 